\title{
Optimasi Posisi Arah Panel Surya Untuk Mendapatkan Intensitas Cahaya Terbaik Menggunaksn Arduino Arduino Mega 2560
}

\author{
Mahendra Eka Setiawan ${ }^{1}$, Chrystia Aji Putra ${ }^{2 *}$, Eka Prakasa Mandyartha ${ }^{3}$ \\ 1,2,3 (Informatika/Fakultas Ilmu Komputer, Universitas Pembangunan Nasional Veteran Jawa Timur) \\ -ajiputra@upnjatim.ac.id \\ eaporakarsa.fik@upnjatim.ac.id \\ *Corresponding author email: mahendraeka95@gmail.com
}

\begin{abstract}
Abstrak - Kebutuhan masyarakat Indonesia akan energi listrik saat ini semakin tinggi. Hal ini seiring dengan pertambahan jumlah penduduk dan juga kemajuan teknologi. Salah satu upaya teknologi untuk memanfaatkan energi cahaya matahari adalah dengan menggunakan Panel Surya. Tujuan dalam penelitian ini adalah merancang optimasi posisi arah panel surya menggunakan arduino yang dapat bergerak untuk pencarian intensitas cahaya terbaik. Sistem pada alat ini menggunakan Arduino Mega 2560 sebagai mikrokontroller yang berfungsi sebagai otak penggerak di program ini dan menggunakan perhitungan fuzzy dengan nilai input dari sensor LDR sebagai syarat banyaknya keluaran untuk penggerak motor. Sistem ini menggunakan 4 sensor LDR yang ditempatkan di setiap sisi Panel Surya yaitu Atas, Bawah, Kanan, dan Kiri. Intensitas cahaya terbaik adalah intensitas cahaya terbesar dari keseluruhan nilai yang dibaca sensor yang akan menentukan nilai output sebagai nilai untuk penggerak motor dengan penghitungan logika fuzzy. Hasil dari uji coba yang dilakukan berdasarkan tempat dan waktu yang berbeda, hasil terbaik Ketika tempat uji coba memiliki intensitas cahaya yang rendah. Maka sensor LDR mendapatkan nilai intensitas cahaya terbaik dan pergerakan alat tidaklah terganggu dikarenakan intensitas cahaya sudah terpenuhi.
\end{abstract}

Kata Kunci- Panel Surya, Arduino Mega2560, Sensor LDR, Motor DC, Logika Fuzzy.

\section{PENDAhULUAN}

Upaya inovatif untuk menggunakan energi siang hari adalah dengan menggunakan Panel Surya. Panel Surya adalah alat yang dapat mengubah energi cahaya menjadi energi listrik. Panel Surya akan menghasilkan energi listrik yang ditunjukkan dengan ukuran daya cahaya yang didapat dari pancaran sinar matahari. Untuk memanfaatkan energi siang hari, dibutuhkan alat untuk optimasi posisi arah panel surya. Semakin mendapatkan intensitas cahaya terbaik, maka semakin banyak daya listrik yang dihasilkan. Dengan cara ini, dibuat sebuah alat dimana panel surya akan bergerak mengikuti intensitas cahaya terbaik yang dikendalikan menggunakan mikrokontroler Arduino Mega 2560.

Salah satu pemanfaatan perangkat ini adalah ketika cahaya menyinari panel surya yang terdapat sensor LDR. Dimana sensor membaca intensitas cahaya yang masuk. Kontribusi dari sensor tersebut nantinya akan dimanfaatkan sebagai pencarian intensitas cahaya terbaik.
Pengembangan alat ini akan sangat bergantung pada teknik kontrol yang digunakan. Kontrol yang digunakan dalam alat ini adalah logika fuzzy control. Logika fuzzy control digunakan sebagai penggerak arah panel surya dengan mencari intensitas cahaya terbaik. Berdasarkan landasan diatas, maka dibuatlah alat Optimasi Posisi Arah Panel Surya Untuk Mendapatkan Intensitas Cahaya Terbaik Menggunakan Arduino Mega 2560. Dengan system control logika fuzzy untuk membantu mengarahkan Panel Surya ke Intensitas Cahaya Terbaik dengan inputan yang didapat dari sensor LDR.

\section{TINJAUAN PUSTAKA}

\section{A. Pengertian Perancangan}

Peranvcangan adalah sebuah penggambaran, perencaanaan dan pembuatan sketsa atau pengaturan beberapa komponen yang terpisah menjadi satu kesatuan yang utuh dan berfungsi sebagai perancangan system yang dapat dirancang dalam bentuk diagram blok system, yang selanjutnya dapat dibuat dalam bentuk nyata atau prototype.

\section{B. Arduino Mega2560}

Arduino merupakan papan berbasis mikrokontroler atau papan sirkuit elektronik open source yang di dalamnya terdapat bagian utama, khususnya chip mikrokontroler dengan tipe AVR dari organisasi Atmel. Mikrokontroler sendiri merupakan sebuah chip atau IC (integrated circuit) yang dapat dikustomisasi menggunakan PC. Alasan untuk memasukkan program ke dalam mikrokontroler adalah agar rangkaian elektronik dapat membaca informasi, mengukur informasi dan kemudian menghasilkan yield yang ideal. Jadi mikrokontroler berfungsi sebagai pikiran yang mengontrol interaksi informasi dan hasil dari rangkaian elektronik.

\section{Sensor LDR}

Light Light Reliant Resistor (LDR) Sensor LDR adalah sejenis resistor yang mengubah nilai obstruksi sesuai kekuatan cahaya yang didapatnya. Cahaya redup menyebabkan nilai oposisi LDR meningkat, sedangkan dalam kondisi cahaya yang sangat baik harga penghalang menurun. LDR terdiri dari lingkaran semikonduktor yang memiliki dua terminal pada permukaannya, selama kondisi redup nilai material dari pelat memberikan jumlah elektron bebas yang umumnya sedang 
sehingga ada beberapa elektron yang membawa muatan elektron. Kerangka kerja pelacak berbasis sinar matahari dinamis yang serbaguna menggunakan sensor, khususnya LDR (Light Ward Resistor). LDR (Light Ward Resistor) adalah sejenis resistor yang umumnya digunakan sebagai pelacak cahaya. Kerangka pelacak bertenaga matahari dinamis portabel ini menggunakan 4 LDR untuk mengidentifikasi perkembangan matahari di utara, timur, barat, dan selatan.

\section{Panel Surya}

PanelSurya yang dapat berubah dari siang hari menjadi energi. Saat mengirimkan papan berbasis sinar matahari, produsen harus menjamin bahwa sel berbasis matahari secara elektrik terkait satu sama lain dalam kerangka. Sel tenaga matahari juga harus dilindungi dari kelembaban dan kerusakan mekanis karena hal ini pada dasarnya dapat melemahkan kemampuan panel berbasis matahari, dan menurunkan masa pakai normal.

Sel berbasis sinar matahari sebagian besar memiliki harapan hidup 20 tahun, yang umumnya menyiratkan bahwa pemilik papan berbasis matahari tidak akan mengalami penurunan produktivitas yang besar. Meskipun demikian, terlepas dari kemajuan terbaru dalam inovasi, sebagian besar bisnis papan bertenaga matahari saat ini mencapai kemampuan 15\% dan ini tidak diragukan lagi adalah salah satu alasan utama mengapa industri energi berbasis sinar matahari masih belum layak untuk bersaing. produk minyak bumi. Jarang papan bisnis berbasis matahari melewati $20 \%$ efektivitas.

\section{E. Logika fuzzy sugeno}

Metode Sugeno seperti strategi Mamdani, perbedaannya terletak pada hasil. Dalam dasar pemikiran Sugeno yang lembut, rangka adalah perangkat yang mantap, bukan perangkat yang halus. Pekerjaan partisipasi dalam strategi halus Sugeno dikenal sebagai pekerjaan tunggal, yaitu pekerjaan pendaftaran yang memiliki nilai partisipasi 1 dalam kapasitas nyata soliter dan 0 dalam kapasitas asli lainnya. Siklus defuzzifikasi pada strategi Sugeno lebih efektif dibandingkan dengan teknik mamdani. Hal ini dikarenakan pada teknik fluffy Sugeno menghitung kapasitas luluh dari aturan ke-i, terakhir, dan hasil adalah bobot normal. Dibandingkan dengan teknik mamdani yang harus memastikan wilayah di bawah kurva partisipasi kerja variabel hasil. Sisi positif dari pemikiran halus Sugeno adalah bahwa permintaan nol secara teratur masuk akal untuk kebutuhan tampilan yang berbeda.

\section{Metodologi Penelitian}

Penulis menjelaskan tentang rencana pembangunan Prototype alat Optimasi posisi arah panel surya menggunakan Arduino. Maka penulis telah melakukan penelitian berdasarkan metode yang dijalankan. Terdapat rincian tentang urutan langkahlangkah yang dibuat secara logis sehingga dapat dijadikan pedoman yang jelas dan mudah untuk menyelesaikan Prototype alat optimasi posisi arah panel surya ini menggunakan mikrokontroler Arduino.

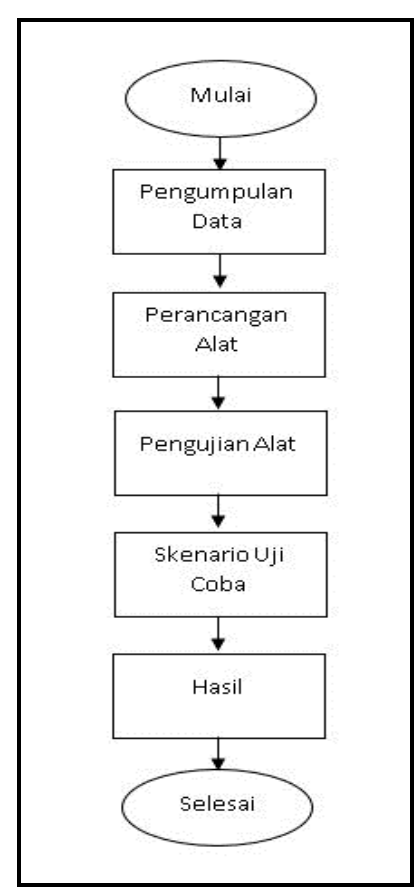

Gbr.1 Alur Penelitian.

Selanjutnya peneliti akan menerapkan program tersebut, apabila terjadi error pada percobaan program maka akan dilakukan perbaikan hingga program dapat berjalan sesuai dan benar. Kemudian peneliti akan Menyusun laporan unrtuk penelitian tersebut.

\section{A. Pengumpulan Data}

Tahap ini adalah bermacam-macam data yang diidentifikasi dengan segmen usaha terakhir. Demikian juga tahapan ini merupakan metode pengumpulan informasi dari beberapa buku, diari, postulasi, proposisi dan tulisan lain yang dapat digunakan sebagai semacam perspektif percakapan dalam hal ini. Pemeriksaan ini diidentifikasi dengan sumber informasi di web sebagai artikel tentang inovasi berbasis intensitas cahaya, tenaga baru dan berkelanjutan, artikel darurat energi atau konsekuensi penelitian masa lalu sebagai bahan referensi bagi ilmuwan masa depan. Pada titik itu akan dilakukan pengembangan ide yang masuk akal untuk menyingkirkan usaha terakhir. Diantaranya, pengejaran dilakukan pada tampilan panel surya berdasarkan kerangka mekanis, segmen yang digunakan, dan model sensor yang akan digunakan.

\section{B. Perancangan Alat}

Pada tahap ini, perencanaan dan perakitan kerangka mekanis dan sensor yang akan digunakan telah selesai. Selain itu, peralatan asli atau kerangka mekanis dibuat dengan apa yang baru-baru ini direncanakan. Dan juga perancangan system kendali logika fuzzy yang digunakan untuk mempercepat dan memperhalus putaran motor. 


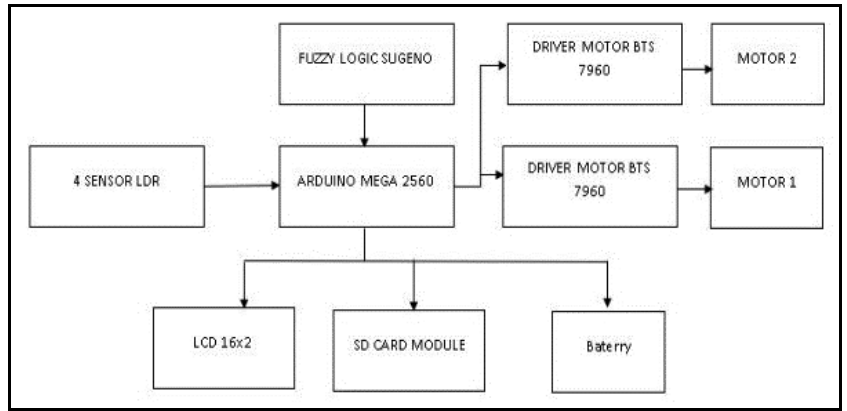

Gbr.2 Diagram Blok perancangan alat.

Prototype optimasi posisi arah panel surya system direncanakan menggunakan aluminium sebagai tepian / penopang mengikuti keadaan papan berorientasi matahari dengan tinggi 20, dan papan PCB yang memiliki ukuran yang tidak terlalu besar dan ringan sebagai papan. untuk meletakkan segmen. Keputusan material ini tergantung pada konstruksi yang kokoh dan ringan. Bagian-bagian seperti segmen potensiometer, baterai, terminal, mikrokontroler Arduino Mega, dan rangkaian LCD disimpan di dalam kotak kontrol, sedangkan moto diletakkan pada dukungan Panel Surya. Jalannya aksi model kerangka tarcking bertenaga matahari pada papan berbasis matahari Arduino.

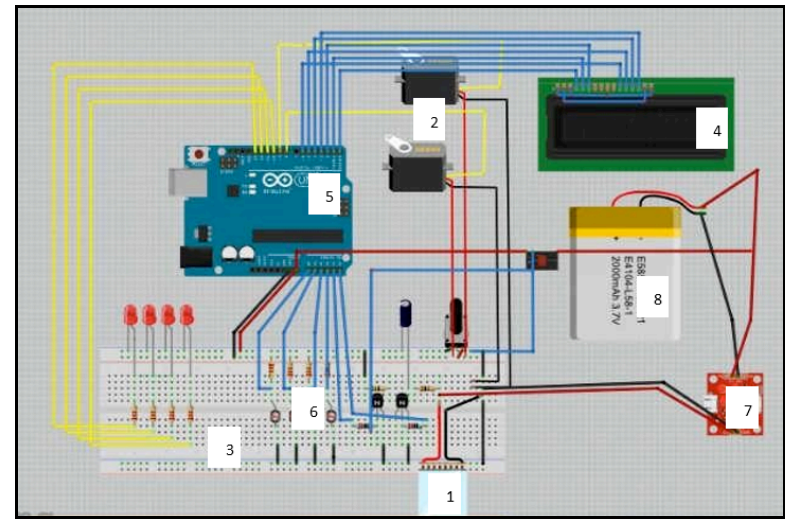

Gbr.3 Rangkaian Fisik.

Keterangan:

1. Papan Panel surya

2. Motor Driver bts 7960

3. Sensor LDR

4. LCD

5. Arduino Mega2560

6. Breadboard

7. Rangkaian Batery

8. Batery

Perancangan system control fuzzy dilakukan pembuatan software pada arduino. Sistem kontrol yang dipakai adalah berbasis Fuzzy Logic. Jadi, pembuatan coding akan didasarkan pada kontrol Fuzzy Logic. Tujuan digunakan kontrol Fuzzy Logic adalah supaya respon dari motor cepat dan akan memperhalus putaran motor.

\section{Pembentukan Himpunan Fuzzy}

Sistem yang dibangun menggunakan 4 inputan LDR yaitu untuk Atas dan Bawah, Kanan dan Kiri. Pada data LDR (cahaya) dibagi menjadi 3 kriteria, yaitu gelap (0-40), normal (30-70), terang (60-100). Variabel terbukanya motor yaitu $\mathrm{CW}$ (0), OFF (50), CCW (100). Penjelasan CW (kanan), OFF (berhenti), $\mathrm{CCW}$ (kiri).

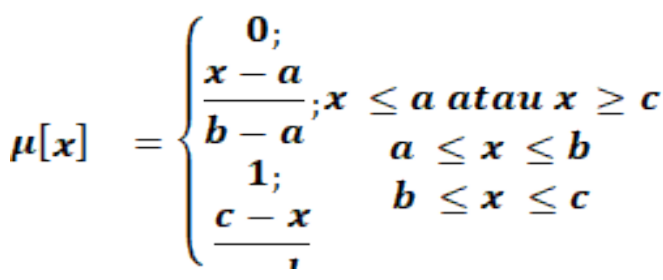

Rumus Fungsi Keanggotaan.

\section{Pembentukan Aturan Fuzzy}

Setelah proses fuzzifikasi selesai dilanjutkan dengan proses inferensi. Inferensi adalah proses penggabungan banyak aturan berdasarkan data yang tersedia. Dari uraian di atas, telah terbentuk 6 himpunan fuzzy sebagai input, yaitu: gelap, normal, terang disetiap LDR nya ditambah dengan 3 himpunan kondisi putaran motor DC sebagai output, yaitu : $\mathrm{CW}, \mathrm{OFF}, \mathrm{CCW}$.

TABLE 1

FUZZY RULE MOTORUPDOWN.

\begin{tabular}{|l|l|l|l|}
\hline Atas/Bawah & $\begin{array}{l}\text { Bawah } \\
\text { Gelap }\end{array}$ & $\begin{array}{l}\text { Bawah } \\
\text { Normal }\end{array}$ & $\begin{array}{l}\text { Bawah } \\
\text { Terang }\end{array}$ \\
\hline AtasGelap & OFF (R1) & CCW (R2) & CCW (R3) \\
\hline AtasNormal & CW (R4) & OFF (R5) & CCW (R6) \\
\hline Atas Terang & CW(R7) & CW (R8) & OFF (R9) \\
\hline
\end{tabular}

TABEL 2

FUZZY RULE MOTOR LEFREG

\begin{tabular}{|l|l|l|l|}
\hline Atas/Bawah & $\begin{array}{l}\text { Bawah } \\
\text { Gelap }\end{array}$ & $\begin{array}{l}\text { Bawah } \\
\text { Normal }\end{array}$ & $\begin{array}{l}\text { Bawah } \\
\text { Terang }\end{array}$ \\
\hline AtasGelap & OFF (R1) & CCW (R2) & CCW (R3) \\
\hline AtasNormal & CW (R4) & OFF (R5) & CCW (R6) \\
\hline Atas Terang & CW(R7) & CW (R8) & OFF (R9) \\
\hline
\end{tabular}

\section{Defuzzyfikasi}

Setelah selesai menghitung tiap rule di atas dengan mengambil nilai MIN dari setiap variable yang sesuai dengan rule, maka selanjutnya menghitung Defuzzyfikasi dengan menggunkan rumus seperti berikut : 
$\mathrm{Z}=\alpha$-Predikat $1(\mathrm{z} 1)+\alpha-$ Predikat 2(z2) $+\alpha-$ Predikat 3(z3) $+\alpha-$ Predikat 4(z4)

$\alpha-$ Predikat $1+\alpha-$ Predikat $2+\alpha-$ Predikat $3+\alpha-$ Predikat 4

proses perhitungan Defuzzyfikasi :

$Z=0,5(50)+0,5(100)+0,5(0)+0,5(50)$

$0,5+0,5+0,5+0,5$

$Z=25+50+0+50$

$Z=50$

Hasil dari perhitungan manual untuk menentukan output pergerakan motor berdasarkan inputan dari LDR (Atas,Bawah) dan LDR (Kanan,Kiri) dengan nilai inputan dari semua LDR sebesar 35 dan menyesuaikan dengan rule maka ditemukan hasil pergerakan Motor 50 (OFF) untuk setiap MotorUpDown dan Motorlefreg.

\section{Pengujian Alat}

Pengujian alat dilakukan dengan tujuan apakah sistem mekanik dapat dan software berjalan sesuai dengan rancangan dan memastikan beban sistem keseluruhan masih dibawah dari torsi motor yang dipakai. Agar tidak mengganggu kinerja dari alat yang telah di buat.

\section{Skenario Uji Coba}

Metode pengujian yang digunakan pada penelitian ini adalah metode pengujian langsung yaitu dengan cahaya buatan seperti bola lampu. Digunakan untuk menguji fungsi-fungsi khusus dari perangkat lunak yang dirancang. Kebenaran perangkat lunak yang diuji hanya dilihat berdasarkan keluaran yang dihasilkan dari data atau kondisi masukan yang diberikan untuk fungsi yang ada tanpa melihat bagaimana proses untuk mendapatkan keluaran tersebut. Dari keluaran yang dihasilkan, kemampuan program dalam memenuhi kebutuhan pemakai dapat diukur sekaligus dapat diiketahui kesalahan-kesalahannya. Dalam pengujian alat ini di lakukan di 2 tempat dan 2 waktu yang berbeda. Untuk tempat dilakukan didalam ruangan dan diluar ruangan. Dan untuk waktu di lakukan pada siang hari dan malam hari.Data yang di ambil dalam uji coba adalah posisi awal dari alat dan tingkat intensitas cahaya awal sebelum uji coba dilakukan, jarak cahaya bola lampu yang digunakan adalah $<1$ meter dan $>1$ meter, intensitas cahaya terbaik yang dibaca oleh alat.

\section{HASIl DAN PEMBAhasan}

Hasil dari pengujian alat adalah tahapan terakhir untuk mengetahui apakah alat optimasi posisi arah panel surya yang dirancang sudah sesuai dengan apa yang diinginkan. serta bertujuan untuk mengetahui alat atau komponen yang telah dibuat apakah bekerja sesuai dengan yang diinginkan. Scenario uji coba yang telah dilakukan di 2 tempat dan 2 waktu yang berbeda. Untuk tempat dilakukan didalam ruangan dan diluar ruangan. Dan untuk waktu di lakukan pada siang hari dan malam hari. jarak cahaya bola lampu yang digunakan adalah $<1$ meter dan $>1$ meter, intensitas cahaya terbaik yang dibaca oleh alat.

A. Uji coba ke-1

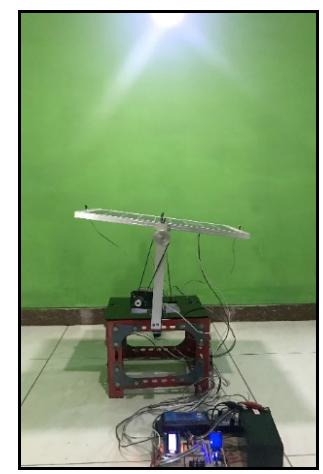

Gbr.5 Posisi dari panel surya saat uji coba ke-2.

Gambar 5 diatas adalah posisi dari panel surya saat dilakukan uji coba dengan bola lampu dengan jarak $<1$ meter. Terlihat panel surya menghadap kearah bola lampu.

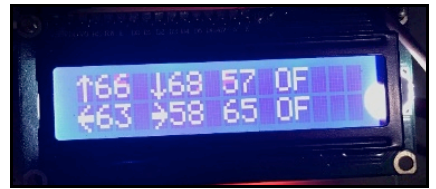

Gbr.6 Intensitas cahaya yang didapat sensor LDR.

Gambar 6 diatas adalah nilai dari intensitas cahaya terbaik yang di dapat dari sensor ldr didalam ruangan yang ditampilkan oleh lcd saat dilakukan uji coba menggunakan bola lampu dengan jarak $<1$ meter.

Dari hasil uji coba diatas terlihat bahwa panel surya mengarah ke cahaya buatan (bola lampu) yang berada diatas dikarenakan intensitas cahaya terbaik yang didapat oleh sensor terpenuhi. Dengan nilai sensor ldr atas (66), bawah (68), kiri (63), kanan (58). Dan nilai output dari MotorAtasBawah (67) dan MotorKananKiri (65).

B. Uji coba ke-2

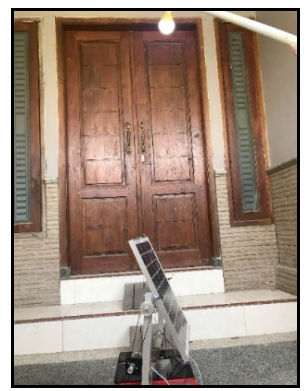

Gbr.7 Posisi dari panel surya saat uji coba ke-2. 
Gambar 7 diatas adalah posisi dari panel surya saat dilakukan uji coba dengan bola lampu dengan jarak $>1$ meter. Terlihat panel surya tidak bergerak dari posisi awal dikarenakan jarak bola lampu dan intensitas cahaya terbaik yang didapat oleh sensor lebih besar dari bola lampu.

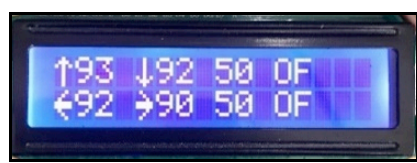

Gbr.8 Intensitas cahaya yang didapat sensor LDR.

Gambar 8 diatas adalah nilai dari intensitas cahaya terbaik yang di dapat dari sensor ldr diluar ruangan yang ditampilkan oleh led saat dilakukan uji coba menggunakan bola lampu dengan jarak $>1$ meter.

Dari hasil uji coba diatas terlihat bahwa panel surya tidak bergerak dari posisi awal dikarenakan jarak dari cahaya buatan (bola lampu) yang berada disebelah kanan atas dikarenakan intensitas cahaya terbaik yang didapat oleh sensor lebih besar dari bola lampu. Dengan nilai sensor ldr atas (93), bawah (92), kiri (92), kanan (90). Dan nilai output dari MotorAtasBawah (50) dan MotorKananKiri (50).

\section{Uji coba ke-3}

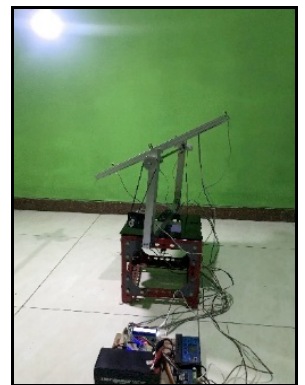

Gbr.9 Posisi dari panel surya saat uji coba ke-3.

Gambar 9 diatas adalah posisi dari panel surya saat dilakukan uji coba dengan bola lampu dengan jarak $<1$ meter. Terlihat panel surya menghadap kearah bola lampu.

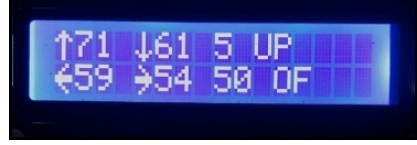

Gbr.10 Intensitas cahaya yang didapat sensor LDR.

Gambar 10 diatas adalah nilai dari intensitas cahaya terbaik yang di dapat dari sensor ldr didalam ruangan yang ditampilkan oleh lcd saat dilakukan uji coba menggunakan bola lampu dengan jarak $<1$ meter.

Dari hasil uji coba diatas terlihat bahwa panel surya mengarah ke cahaya buatan (bola lampu) yang berada disebelah kiri dikarenakan intensitas cahaya terbaik yang didapat oleh sensor. Dengan nilai sensor ldr atas (71), bawah (61), kiri (59), kanan (54). Dan nilai output dari MotorAtasBawah (5) dan MotorKananKiri (50).

D. Uji coba ke-4

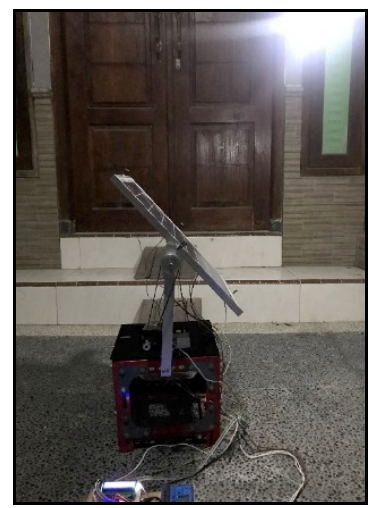

Gbr.11 Posisi dari panel surya saat uji coba ke-4.

Gambar 11 diatas adalah posisi dari panel surya saat dilakukan uji coba dengan bola lampu dengan jarak $<1$ meter. Terlihat panel surya menghadap kearah bola lampu.

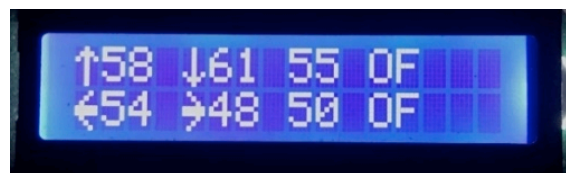

Gbr.12 Intensitas cahaya yang didapat sensor LDR.

Gambar 12 diatas adalah nilai dari intensitas cahaya terbaik yang di dapat dari sensor ldr diluar ruangan yang ditampilkan oleh lcd saat dilakukan uji coba menggunakan bola lampu dengan jarak $<1$ meter.

Dari hasil uji coba diatas terlihat bahwa panel surya mengarah ke cahaya buatan (bola lampu) yang berada disebelah kanan atas dikarenakan intensitas cahaya terbaik yang didapat oleh sensor terpenuhi. Dengan nilai sensor ldr atas (58), bawah (61), kiri (54), kanan (48). Dan nilai output dari MotorAtasBawah (55) dan MotorKananKiri (50).

\section{KESIMPULAN DAN SARAN}

Dalam bab ini berisi tentang kesimpulan dan saran dari pengujian alat pada tugas akhir.

\section{A. Kesimpulan}

Kesimpulan dari pengujian alat pada tugas akhir mengenai alat optimasi posisi panel adalah :

1. Alat yang dirancang sesuai dengan cara kerja yang diinginkan. dan untuk pergerakan juga sesuai dengan output dari Arduino Mega 2560.

2. Dari uji coba yang dilakukan berdasarkan tempat dan waktu yang berbeda, hasil yang terbaik ketika alat di uji didalam ruangan dengan jarak cahaya buatan $<1$ meter dan waktu dimalam hari, dikarenakan intensitas cahaya didalam ruangan tidaklah tinggi. Yaitu pada uji coba ke-3 pengambilan gambar dari 1-3 jarak $<1$ meter. 
3. Ada juga hasil yang tidak baik dikarenakan alat tidak berjalan mengikuti cahaya buatan. Uji coba yang dilakukan waktu siang hari dengan jarak $>1$ meter dan dilakukan diluar ruangan. Dapat mempengaruhi sensor dikarenakan intensitas cahaya yang ada diluar ruangan sangat tinggi maka alat tidak bisa mengikuti cahaya buatan. Yaitu pada uji coba ke-2 pengambilan gambar dari 1-3 jarak $>1$ meter.

B. Saran

Saran dari pengujian alat pada tugas akhir mengenai. Berdasarkan hasil dari tugas akhir tersebut, masih ada beberapa kekurangan dari tugas akhir ini karena materi yang minim, kemampuan dan waktu. Sehingga dengan hasil yang diperoleh, maka perlu diperhatikan Kembali dalam pembuatan alat serta proses percobaan, antara lain sebagai berikut :

1. Untuk uji coba selanjutnya dapat dicoba dengan intensitas cahaya yang lebih tinggi seperti sinar matahari lansung.

2. Dalam pengembangan selanjutnya sebaiknya ditambahkan IOT agar dapat mengontrol alat dari jauh.

3. Pembuatan alat bisa lebih efisien agar tidak terkendala dengan cuaca (hujan).

Untuk pengaplikasian selanjutnya dalam dunia industry sebaiknya daya Panel Surya diperbesar agar energi matahari dapat diserap lebih banyak dan maksimal.hypertext link dan bagian bookmark akan dihapus. Jika paper perlu merujuk ke alamat email atau URL di artikel, alamat atau URL lengkap harus diketik dengan font biasa.

\section{REFERENSI}

[1] Jeneiro Rezkyanzah. 2016. PERANCANGAN SOLAR TRACKER BERBASIS ARDUINO SEBAGAI PENUNJANG SISTEM KERJA SOLAR CELL DALAM PENYERAPAN ENERGI MATAHARI. Teknik Informatika. Fakultas Teknologi Industri. UPN "Veteran" Jatim.

[2] KHALID FADHLULLAH. 2017. SOLAR TRACKING SYSTEM BERBASIS ARDUINO. Sarjana Komputer. Jurusan Teknik Informatika. Fakultas Sains dan Teknologi. UIN Alauddin Makassar.

[3] Roni Syafrialdi, Wildian. 2015. RANCANG BANGUN SOLAR TRACKER BERBASIS MIKROKONTROLER ATmega8535 DENGAN SENSOR LDR DAN PENAMPIL LCD. Jurusan Fisika. FMIPA. Universitas Andalas Kampus Unand. Limau Manis. Padang. 